\title{
Qualitative Assessment of Co-compost Prepared by Paddy straw and Pressmud using Microbial Consortia
}

\author{
Sushila Devi*, Nandni, Tanvi and Sneh Goyal \\ Department of Microbiology, CCS Haryana Agricultural University, Hisar, India \\ *Corresponding author
}

\section{A B S T R A C T}

\begin{tabular}{|l|}
\hline Ke y w o r d s \\
Paddy straw, \\
$\begin{array}{l}\text { Pressmud, Co- } \\
\text { composting, Quality } \\
\text { compost, Plant } \\
\text { growth }\end{array}$ \\
\hline Article Info \\
\hline $\begin{array}{l}\text { Accepted: } \\
\text { 04 December } 2020 \\
\text { Available Online: } \\
\text { 10 January } 2021\end{array}$ \\
\hline
\end{tabular}

Keywords

Paddy straw, Pressmud, Cocomposting, Quality compost, Plant growth

\section{Introduction}

Paddy straw and pressmud are agricultural and industrial wastes which are generated in rice fields and sugar mill, respectively. Paddy straw is a vegetative part of rice plant (Oryza sativa), cut at grain harvest or after. It is a major agricultural waste in rice producing countries. About 95 million tons of paddy straw is produced in the Indo-Gangetic plains which is about 39\% of total crop residue generated (Sidhu et al., 2003). In Haryana, about 6 million tons of paddy straw is produced annually and approximately $63 \%$ of this is burnt which causes environmental and health problems (Reinhard et al., 2001).The open field burning is a major source of air pollutants such as carbon dioxide, carbon monoxide, un-burnt carbon as well as traces of methane, nitrogen oxide and comparatively less amount of sulphur dioxide (Tipayarom and Oanh, 2007). Paddy straw burning is also known to emit particulate matter and other elements such as dioxins and furans that affect human health (Torigoe et al., 2000; Gadde et al., 2009). Based on a study of the 
Department of Science and Technology (DST), burning of rice straw and other agricultural wastes contribute more dioxins and furans to air and land than vehicle emissions.

Pressmud is a residue of the filtration of sugarcane juices which is soft, spongy, amorphous and dark brown material containing sugar, fibre, coagulated colloides including cane wax, albuminoids and inorganic salts (Ramaswamy et al., 1999). The composition of pressmud depends upon quality of cane and process of cane juice clarification. Sugar industry in India is the second largest agro processing industry after textiles. A typical sugar factory generates large quantity of byproducts like bagasse, pressmud and molasses (Patil et al., 2000). India produces on an average 270 million tons of sugarcane per year (Zeyer et al., 2004) and for every 100 tons of sugarcane, 3 tons of pressmud is left behind as a byproduct (Solomon, 2011). This industrial waste is mostly used as soil conditioner, soil fertilizer, for wax production, cement and paint manufacturing and as a foaming agent (Van der Poel et al., 1998). However, due to its bulky nature and wax content, it usually gives less benefit when applied directly into soil (Joshi and Sharma, 2010). Composting is a well-known system for rapid stabilization and humification of organic matter. This process is aerobic and uses various microorganisms such as bacteria, fungi and actinomyces to break down the organic compounds into much simpler substances. During composting, microbes consume oxygen when fed upon organic matter. This generates a large amount of heat, large quantities of carbon dioxide and water vapours are released into the air. The carbon dioxide and water losses can amount to half the weight of the initial organic materials, thus composting reduces both the volume and mass of the raw materials while transforming them into beneficial humus like material (Patil et al., 2000). Composting is a simple, non technical and low-investment process that adds value to organic solid wastes by converting them into organic fertilizer known as compost (Neves et al., 2009).

\section{Materials and Methods}

Paddy straw was obtained from Farmer's field of village Mangali, Distt. Hisar (Haryana) India and Pressmud from Sugar mill, Meham (Rohtak) respectively. The cattle dung and microbial consortium of three fungi (Aspergillus awamorii, Paecilomyces fusisporus and Trichoderma viride) used during the present investigation was obtained from Animal Science Department and Department of Microbiology, CCS Haryana Agricultural University, Hisar respectively.

\section{Composting experiment}

Composting of paddy straw and pressmud was carried out in the $1.5 \times 1.5 \times 1.5 \mathrm{ft}$. size pits using following treatments:

Ten kilograms of compostable material was taken on dry weight basis and mixed with above amendments. The material was put in cemented pits and allowed to decompose. Moisture was adjusted to $60 \%$ of water holding capacity (WHC) and initial C: $\mathrm{N}$ ratio was maintained to 40-50:1. Two turnings of compostable material were done at 15 and 30 days of intervals. The samples were drawn at $0,15,30,45,60,75$ and 90 days for analysis of different parameters.

\section{Chemical analysis of compostable samples}

\section{Organic carbon}

Organic carbon was determined by dry combustion method (Nelson and Sommers, 1982). 
Weight of compostable sample $=$ Weight of compostable sample with crucible - Empty crucible

Weight of Ash $=$ Weight of ash with crucible - Empty crucible

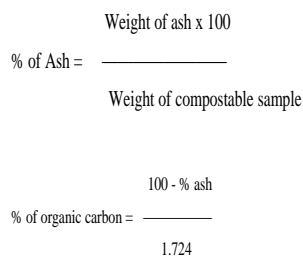

\section{Total nitrogen}

Total nitrogen was estimated by Kjeldahl's method (Bremner, 1982)

Percent $\mathrm{N}$ was calculated as follows:

$1 \mathrm{ml}$ of $0.02 \mathrm{~N} \mathrm{HCl}=0.28 \mathrm{mg} \mathrm{N}$

$$
\% \mathrm{~N}=\frac{0.28(\mathrm{~S}-\mathrm{B}) \times 100}{\text { Weight of compostable sample }(\mathrm{mg})}
$$

Where,

$\mathrm{S}=\mathrm{ml}$ of $0.02 \mathrm{~N} \mathrm{HCl}$ used for compostable sample

$\mathrm{B}=\mathrm{ml}$ of $0.02 \mathrm{~N} \mathrm{HCl} \mathrm{used} \mathrm{for} \mathrm{blank}$

\section{Ammoniacal and nitrate nitrogen (Bremner, 1965)}

Compostable sample (10 g) was taken in 250 $\mathrm{ml}$ conical flask and $100 \mathrm{ml}$ of $2 \mathrm{M} \mathrm{KCl}$ was added. Flask was kept on a rotary shaker (160 rpm) for $1 \mathrm{~h}$. The suspension was filtered through Whatman no. 1 filter paper and filtrate was analyzed by steam distillation procedure used for determination of ammoniacal and nitrate nitrogen as follows

$1 \mathrm{ml}$ of $0.005 \mathrm{~N} \mathrm{H} 2 \mathrm{SO} 4=70 \mu \mathrm{g} \mathrm{N}$

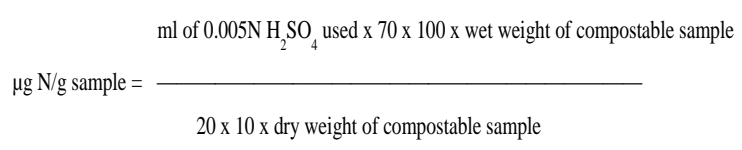

Total phosphorus

The total phosphorus content in the compostable sample was determined by the method of John (1970).

\section{Calculation}

$\mathrm{mg} / \mathrm{kgcompostable} \mathrm{sample}=\frac{\mu \mathrm{g} \mathrm{P} / \mathrm{ml} \text { corresponding to absorbance } \times 50 \times 100}{\mathrm{ml} \text { of aliquot taken for color development } \times \text { weight of the compost }}$

\section{Total potassium}

Total Potassium in the samples was estimated using Flame photometer by direct feeding method (Jankowski et al., 1961).

\section{Calculations}

Total $\mathrm{K}(\%)=$ Concentration of $\mathrm{K}$ in ppm corresponding to Flame photometer reading $\times$ dilution factor $\times 100 /$ weight of soil sample (g) $\times 10000$

\section{Carbon-dioxide evolution in finished compost}

Carbondioxide evolution was determined by measuring $\mathrm{CO}_{2}$ evolved in compost for 4 weeks by method of Pramer and Schmidt (1964) with slight modification.

\section{Calculations}

One $\mathrm{ml}$ of $1 \mathrm{~N} \mathrm{HCl}$ used against $1 \mathrm{~N} \mathrm{NaOH}=$ $22 \mathrm{mg}$ carbon dioxide

mg CO2-C/100 g compostable sample $=\{(\mathrm{B}-$ R) $\times 22 \times 12 \times 10\} / 44$

Where, 
$\mathrm{B}=\mathrm{ml}$ of $1 \mathrm{~N} \mathrm{HCl}$ used in blank

$\mathrm{R}=\mathrm{ml}$ of $1 \mathrm{~N} \mathrm{HCl}$ used in flask with compostable sample

\section{Water soluble carbon}

Water soluble carbon in compost was determined by wet digestion method (Kalembassa and Jenkinson, 1973).

\section{Calculations}

Normality of FAS (Ferrous Ammonium Sulfate $)(x)=0.5 \times 20 / y$

$\%$ Organic $\mathrm{C}=\mathrm{x}(\mathrm{Vh}-\mathrm{Vs}) \times 3 \times 100 / \mathrm{W} \times$ 1000

Where,

$\mathrm{x}=$ Normality of FAS

$\mathrm{y}=$ Volume of FAS used for cold blank (ml)

$\mathrm{Vh}=$ Volume of FAS used for hot blank (ml)

$\mathrm{Vs}=$ Volume of FAS used for sample (ml)

$\mathrm{W}=$ Weight of compostable sample in grams

\section{Results and Discussion}

\section{Initial analysis of compostable material}

Table 1 shows the initial analysis of paddy straw and pressmud for organic $\mathrm{C}$, total and available $\mathrm{N}$, total $\mathrm{P}$ and $\mathrm{K}$, ammonical-N, nitrate- $\mathrm{N}$ and $\mathrm{C}: \mathrm{N}$ ratio

\section{Analysis of compostable material at} different stages of composting

\section{Changes in total organic $\mathrm{C}$}

Organic carbon decreased significantly in the control (T1 and T2) as well as in all other treatments with time (Table 2). It was 47.96 and $36.27 \%$ initially in control and decreased to 35.10 and $25.15 \%$ respectively after 90 days of composting. Minimum organic $\mathrm{C}$
(19.39\%) was recorded in the treatment 6 having paddy straw and pressmud (1:2) + cattle dung $(10 \%)+$ microbial consortia after 90 days of composting. There was a significant decline in \% organic carbon with the inoculation of microbial consortia in all the treatments as compared to the treatments not having microbial consortia.

\section{Total and available $\mathbf{N}$}

Table 3 shows the amount of total $\mathrm{N}$ in different treatments at different days of composting. The total $\mathrm{N}$ content increased significantly from $0.80 \%$ and 1.07 to 1.04 and $1.12 \%$ during composting in control $\mathrm{T} 1$ and $\mathrm{T} 2$ respectively. Maximum total $\mathrm{N}(1.25 \%)$ was recorded in T6 having paddy straw and pressmud $(1: 2)+$ cattle dung $(10 \%)+$ microbial consortia after 90 days of composting followed by T5 $(1.23 \%)$ having paddy straw and pressmud (1:2) + cattle dung $(10 \%)$.

\section{Changes in ammoniacal nitrogen at different days of composting}

The ammoniacal nitrogen decreased significantly with time during composting in all the treatments. After 90 days of composting, minimum amount of ammoniacal - $\mathrm{N}$ was recorded in treatment $\mathrm{T} 6$ (5.14 $\mathrm{mg} / \mathrm{kg}$ ) having paddy straw and pressmud $(1: 2)$ +cattle dung $(10 \%)+$ microbial consortia and maximum amount of ammoniacal nitrogen was observed in treatment $\mathrm{T} 11(5.55 \mathrm{mg} / \mathrm{kg})$ having paddy straw and pressmud (3:1) + cattle dung $(10 \%)$.

Table 5 shows the changes in nitrate nitrogen at different days of composting. Amount of nitrate nitrogen increased significantly and varied from $180 \mathrm{mg} / \mathrm{kg}$ to $527 \mathrm{mg} / \mathrm{kg}$ and was maximum in the treatment T6 $(527 \mathrm{mg} / \mathrm{kg})$ having paddy straw and pressmud (1:2) 
+cattle dung $(10 \%)+$ microbial consortia and minimum for $\mathrm{T} 1(394 \mathrm{mg} / \mathrm{kg})$ having paddy straw alone + cattle dung $(10 \%)$ after 90 days of composting.

\section{$\mathrm{C}: \mathrm{N}$ ratio}

The $\mathrm{C}: \mathrm{N}$ ratio declined from 59.95 and 33.89 to 33.75 and 22.45 in control (T1 and T2) respectively, after 90 days of composting. A significant reduction in $\mathrm{C}$ : $\mathrm{N}$ ratio of the compost was observed in all the treatments. With the addition of microbial consortia, decline in $\mathrm{C} / \mathrm{N}$ ratio was more as compared to treatments, not having microbial consortia. Treatment T6 having paddy straw and pressmud (1:2) +cattle dung (10\%) + microbial consortia had minimum $\mathrm{C} / \mathrm{N}$ ratio (15.51) than treatments without microbial consortia.

\section{Total P}

Table 7 shows the amount of total $\mathrm{P}$ in different treatments at different days of composting. Total phosphorous content increased significantly in composting of paddy straw and pressmud in different ratios with or without microbial consortia after 90 days of composting. The amount of total phosphorous varied from 185 to $1035 \mathrm{mg} / \mathrm{kg}$. It was 250 and $185 \mathrm{mg} / \mathrm{kg}$ in control initially and increased to 659 and $332 \mathrm{mg} / \mathrm{kg}$ respectively after 90 days of composting. Maximum amount of total phosphorous was observed in treatments T6 $(1035 \mathrm{mg} / \mathrm{kg})$ after 90 days of composting followed by T10 (1020 $\mathrm{mg} / \mathrm{kg}$ ).

Table.1 Showing different treatments

\begin{tabular}{|c|l|}
\hline Sr.No. & \multicolumn{1}{|c|}{ Treatments } \\
\hline T1 & Paddy straw alone + Cattle dung (10\%) \\
\hline T2 & Pressmud alone + cattle dung $(10 \%)$ \\
\hline T3 & Paddy straw and pressmud $(1: 1)+$ cattle dung $(10 \%)$ \\
\hline T4 & Paddy straw and pressmud $(1: 1)+$ cattle dung $(10 \%)+$ microbial consortia \\
\hline T5 & Paddy straw and pressmud $(1: 2)+$ cattle dung $(10 \%)$ \\
\hline T6 & Paddy straw and pressmud $(1: 2)+$ cattle dung $(10 \%)+$ microbial consortia \\
\hline T7 & Paddy straw and pressmud $(2: 1)+$ cattle dung $(10 \%)$ \\
\hline T8 & Paddy straw and pressmud $(2: 1)+$ cattle dung $(10 \%)+$ microbial consortia \\
\hline T9 & Paddy straw and pressmud $(1: 3)+$ cattle dung $(10 \%)$ \\
\hline T10 & Paddy straw and pressmud $(1: 3)+$ cattle dung $(10 \%)+$ microbial consortia \\
\hline T11 & Paddy straw and pressmud $(3: 1)+$ cattle dung $(10 \%)$ \\
\hline T12 & Paddy straw and pressmud $(3: 1)+$ cattle dung $(10 \%)+$ microbial consortia \\
\hline
\end{tabular}

Table.2 Initial analysis of paddy straw and pressmud

\begin{tabular}{|c|c|c|}
\hline Component & Paddy straw & Pressmud \\
\hline Organic carbon (\%) & 49.02 & 34.50 \\
\hline Total nitrogen (\%) & 0.58 & 1.00 \\
\hline C:N ratio & 84.56 & 34.50 \\
\hline Ammonical nitrogen $(\mathbf{m g} / \mathbf{k g})$ & 8.09 & 7.60 \\
\hline Nitrate Nitrogen $(\mathbf{m g} / \mathbf{k g})$ & 160 & 182 \\
\hline Total phosphorous $(\mathbf{m g} / \mathbf{k g})$ & 207 & 106 \\
\hline Total Potassium (\%) & 0.90 & 0.71 \\
\hline pH & 6.20 & 6.90 \\
\hline
\end{tabular}


Table.3 Changes in total organic $\mathrm{C}$ during different days of composting

\begin{tabular}{|c|c|c|c|c|c|c|c|}
\hline \multirow{2}{*}{ Treatments } & \multicolumn{7}{|c|}{ Total C (\%) } \\
\cline { 2 - 8 } & \multicolumn{7}{|c|}{ Days of composting } \\
\cline { 2 - 8 } & $\mathbf{0}$ & $\mathbf{1 5}$ & $\mathbf{3 0}$ & $\mathbf{4 5}$ & $\mathbf{6 0}$ & $\mathbf{7 5}$ & $\mathbf{9 0}$ \\
\hline T1 & 47.96 & 43.65 & 40.34 & 37.9 & 36.67 & 35.97 & 35.1 \\
\hline T2 & 36.27 & 36.21 & 36 & 32.02 & 29.58 & 25.4 & 25.15 \\
\hline T3 & 41.99 & 34.09 & 30.33 & 28.71 & 27.72 & 24.53 & 24.24 \\
\hline T4 & 41.36 & 30.07 & 28.05 & 27.44 & 25.03 & 21.35 & 20.99 \\
\hline T5 & 33.93 & 32.1 & 29.99 & 27.95 & 24.32 & 22.34 & 20.92 \\
\hline T6 & 33.88 & 30.61 & 27.41 & 23.4 & 22.87 & 21.99 & 19.39 \\
\hline T7 & 43.47 & 39.99 & 37.52 & 35.49 & 34.12 & 32.65 & 29.12 \\
\hline T8 & 43.3 & 38.49 & 36.68 & 34.01 & 33.99 & 30.99 & 28.02 \\
\hline T9 & 33.9 & 30.72 & 28.16 & 26.01 & 25.16 & 24.56 & 23.01 \\
\hline T10 & 33.01 & 30.03 & 27.39 & 24.76 & 23.06 & 22.34 & 22.13 \\
\hline T11 & 44.14 & 39.01 & 36.01 & 35.99 & 33.01 & 31.75 & 30.85 \\
\hline T12 & 42.31 & 36.01 & 34.99 & 32.69 & 30.91 & 29.41 & 29.01 \\
\hline C.D. at 5\% & 0.53 & 0.59 & 0.65 & 1.2 & 0.1 & 0.35 & 0.85 \\
\hline
\end{tabular}

Table.4 Changes in total $\mathrm{N}$ at different days of composting

\begin{tabular}{|l|c|c|c|c|c|c|c|}
\hline \multirow{2}{*}{ Treatments } & \multicolumn{7}{|c|}{ Total N (\%) } \\
\cline { 2 - 8 } & \multicolumn{7}{|c|}{ Days of composting } \\
\cline { 2 - 8 } & $\mathbf{0}$ & $\mathbf{1 5}$ & $\mathbf{3 0}$ & $\mathbf{4 5}$ & $\mathbf{6 0}$ & $\mathbf{7 5}$ & $\mathbf{9 0}$ \\
\hline T1 & 0.80 & 0.86 & 0.98 & 1.02 & 1.03 & 1.03 & 1.04 \\
\hline T2 & 1.07 & 1.09 & 1.10 & 1.11 & 1.11 & 1.12 & 1.12 \\
\hline T3 & 0.83 & 0.86 & 0.99 & 1.01 & 1.02 & 1.06 & 1.10 \\
\hline T4 & 0.80 & 0.83 & 0.97 & 0.99 & 1.05 & 1.10 & 1.12 \\
\hline T5 & 0.92 & 0.86 & 1.01 & 1.02 & 1.04 & 1.11 & 1.23 \\
\hline T6 & 0.99 & 0.83 & 1.03 & 1.05 & 1.07 & 1.15 & 1.25 \\
\hline T7 & 0.77 & 0.79 & 0.81 & 0.83 & 0.94 & 1.02 & 1.06 \\
\hline T8 & 0.78 & 0.81 & 0.83 & 0.85 & 0.97 & 1.06 & 1.09 \\
\hline T9 & 0.80 & 0.82 & 1.04 & 1.07 & 1.11 & 1.14 & 1.16 \\
\hline T10 & 0.82 & 0.85 & 1.09 & 1.11 & 1.16 & 1.18 & 1.19 \\
\hline T11 & 0.74 & 0.78 & 0.85 & 0.90 & 1.03 & 1.12 & 1.14 \\
\hline T12 & 0.76 & 0.81 & 0.87 & 0.92 & 1.06 & 1.16 & 1.16 \\
\hline C.D. at 5\% & 0.01 & 0.02 & 0.01 & 0.01 & 0.02 & 0.03 & 0.01 \\
\hline
\end{tabular}


Table.5 Changes in ammoniacal nitrogen at different days of composting

\begin{tabular}{|c|c|c|c|c|c|c|c|}
\hline \multirow{2}{*}{ Treatment } & \multicolumn{7}{|c|}{ Ammoniacal nitrogen (mg/kg) } \\
\cline { 2 - 7 } & \multicolumn{7}{|c|}{ Days of composting } \\
\cline { 2 - 8 } & $\mathbf{0}$ & $\mathbf{1 5}$ & $\mathbf{3 0}$ & $\mathbf{4 5}$ & $\mathbf{6 0}$ & $\mathbf{7 5}$ & $\mathbf{9 0}$ \\
\hline T1 & 8.19 & 8.09 & 8.08 & 7.86 & 6.45 & 5.6 & 5.07 \\
\hline T2 & 7.81 & 7.56 & 7.21 & 6.95 & 6.32 & 5.11 & 5.02 \\
\hline T3 & 8.05 & 7.88 & 7.45 & 7.21 & 6.39 & 5.42 & 5.17 \\
\hline T4 & 8.09 & 8.01 & 7.99 & 7.45 & 6.42 & 5.45 & 5.15 \\
\hline T5 & 7.99 & 7.84 & 7.39 & 7.19 & 6.29 & 5.32 & 5.21 \\
\hline T6 & 8.02 & 7.97 & 7.85 & 7.12 & 6.32 & 5.35 & 5.14 \\
\hline T7 & 10.24 & 7.9 & 7.56 & 7.25 & 6.41 & 5.46 & 5.24 \\
\hline T8 & 9.66 & 8.03 & 7.95 & 7.56 & 6.45 & 5.49 & 5.21 \\
\hline T1 & 8.04 & 7.9 & 7.45 & 7.25 & 6.32 & 5.35 & 5.45 \\
\hline T10 & 8 & 7.95 & 7.82 & 7.1 & 6.25 & 5.2 & 5.32 \\
\hline T12 & 10.3 & 7.92 & 7.6 & 7.28 & 6.45 & 5.5 & 5.55 \\
\hline C.D. at 5\% & 9.54 & 8 & 7.82 & 7.45 & 6.4 & 5.39 & 5.3 \\
\hline
\end{tabular}

Table.6 Changes in nitrate nitrogen at different days of composting

\begin{tabular}{|c|c|c|c|c|c|c|c|}
\hline \multirow{2}{*}{ Treatments } & \multicolumn{7}{|c|}{ Days of composting } \\
\cline { 2 - 7 } & \multicolumn{7}{|c|}{ itrate nitrogen (mg/Kg) } \\
\cline { 2 - 7 } & $\mathbf{0}$ & $\mathbf{1 5}$ & $\mathbf{3 0}$ & $\mathbf{4 5}$ & $\mathbf{6 0}$ & $\mathbf{7 5}$ & $\mathbf{9 0}$ \\
\hline T1 & 180 & 290 & 320 & 358 & 378 & 388 & 394 \\
\hline T2 & 186 & 300 & 340 & 370 & 395 & 406 & 420 \\
\hline T3 & 182 & 290 & 310 & 365 & 425 & 450 & 475 \\
\hline T4 & 185 & 292 & 325 & 395 & 450 & 498 & 510 \\
\hline T5 & 184 & 289 & 332 & 368 & 420 & 456 & 498 \\
\hline T6 & 190 & 294 & 356 & 398 & 422 & 502 & 527 \\
\hline T7 & 181 & 206 & 320 & 375 & 450 & 460 & 480 \\
\hline T8 & 182 & 210 & 335 & 401 & 475 & 506 & 520 \\
\hline T9 & 189 & 197 & 342 & 378 & 430 & 465 & 500 \\
\hline T10 & 194 & 203 & 370 & 406 & 442 & 504 & 525 \\
\hline T11 & 180 & 260 & 322 & 384 & 451 & 475 & 495 \\
\hline T12 & 182 & 275 & 345 & 410 & 495 & 520 & 522 \\
\hline C.D. at 5\% & 0.9 & 1.5 & 5.6 & 10.2 & 1.1 & 15.4 & 20.6 \\
\hline
\end{tabular}


Table.7 Changes in $\mathrm{C} / \mathrm{N}$ ratio at different days of composting

\begin{tabular}{|c|c|c|c|c|c|c|c|}
\hline \multirow{3}{*}{$\begin{array}{c}\text { Treatmen } \\
\mathbf{t}\end{array}$} & \multicolumn{7}{|c|}{$\mathrm{C}: \mathrm{N}$ ratio } \\
\hline & \multicolumn{7}{|c|}{ Days of composting } \\
\hline & $\mathbf{0}$ & 15 & 30 & 45 & 60 & 75 & 90 \\
\hline T1 & 59.95 & 50.75 & 41.16 & 37.15 & 35.60 & 34.92 & 33.75 \\
\hline $\mathbf{T} 2$ & 33.89 & 33.22 & 32.72 & 28.84 & 26.64 & 23.09 & 22.45 \\
\hline T3 & 50.59 & 39.63 & 30.63 & 28.42 & 27.17 & 23.14 & 22.03 \\
\hline T4 & 51.70 & 36.22 & 28.91 & 27.71 & 23.83 & 19.40 & 18.74 \\
\hline T5 & 36.88 & 37.32 & 29.69 & 27.40 & 23.38 & 20.12 & 17.00 \\
\hline T6 & 34.22 & 36.87 & 26.61 & 22.28 & 21.37 & 19.12 & 15.51 \\
\hline T7 & 56.45 & 50.34 & 45.94 & 42.42 & 35.06 & 32.00 & 27.47 \\
\hline T8 & 54.88 & 47.51 & 43.94 & 40.01 & 34.98 & 29.01 & 25.70 \\
\hline T9 & 42.37 & 37.46 & 27.01 & 24.23 & 22.66 & 21.41 & 19.78 \\
\hline T10 & 40.25 & 35.32 & 25.12 & 22.14 & 19.78 & 18.93 & 18.59 \\
\hline T11 & 59.64 & 50.01 & 42.36 & 39.98 & 32.04 & 28.34 & 27.06 \\
\hline T12 & 55.67 & 44.45 & 40.01 & 35.50 & 29.01 & 25.16 & 25.00 \\
\hline
\end{tabular}

Table.8 Changes in total phosphorous content at different days of composting

\begin{tabular}{|l|c|c|c|c|c|c|c|}
\hline \multirow{2}{*}{ Treatment } & \multicolumn{7}{|c|}{ Total phosphorous (mg/kg ) } \\
\cline { 2 - 8 } & \multicolumn{7}{|c|}{ Days of composting } \\
\cline { 2 - 8 } T1 & $\mathbf{0}$ & $\mathbf{1 5}$ & $\mathbf{3 0}$ & $\mathbf{4 5}$ & $\mathbf{6 0}$ & $\mathbf{7 5}$ & $\mathbf{9 0}$ \\
\hline T2 & 250 & 320 & 402 & 480 & 550 & 608 & 659 \\
\hline T3 & 185 & 191 & 298 & 304 & 325 & 330 & 332 \\
\hline T4 & 212 & 310 & 680 & 720 & 860 & 910 & 980 \\
\hline T5 & 216 & 325 & 735 & 798 & 890 & 945 & 1010 \\
\hline T6 & 198 & 308 & 654 & 735 & 875 & 925 & 990 \\
\hline T7 & 201 & 323 & 765 & 800 & 902 & 980 & 1035 \\
\hline T8 & 245 & 315 & 695 & 735 & 874 & 935 & 990 \\
\hline T9 & 244 & 335 & 750 & 805 & 908 & 985 & 1011 \\
\hline T10 & 188 & 320 & 675 & 755 & 895 & 955 & 978 \\
\hline T11 & 225 & 345 & 703 & 760 & 900 & 975 & 918 \\
\hline T12 & 222 & 360 & 790 & 850 & 926 & 962 & 990 \\
\hline C.D. at 5\% & 0.8 & 13.5 & 20.6 & 30.7 & 22.4 & 12.3 & 14.7 \\
\hline
\end{tabular}


Table.9 Changes in total potassium content at different days of composting

\begin{tabular}{|l|l|l|l|l|l|l|l|}
\hline \multirow{2}{*}{$\begin{array}{l}\text { Treatmem } \\
\text { t }\end{array}$} & \multicolumn{9}{|c|}{ Total K (\%) } \\
\cline { 2 - 9 } & & \multicolumn{7}{|c|}{ Days of composting } \\
\hline T1 & 0.89 & $\mathbf{1 5}$ & $\mathbf{3 0}$ & $\mathbf{4 5}$ & $\mathbf{6 0}$ & $\mathbf{7 5}$ & $\mathbf{9 0}$ \\
\hline T2 & 0.72 & 0.75 & 0.89 & 1.42 & 1.49 & 1.51 & 1.53 \\
\hline T3 & 0.91 & 0.94 & 1.19 & 1.31 & 1.42 & 1.49 & 1.02 \\
\hline T4 & 0.94 & 0.97 & 1.29 & 1.45 & 1.56 & 1.61 & 1.68 \\
\hline T5 & 0.78 & 0.80 & 1.16 & 1.29 & 1.41 & 1.46 & 1.52 \\
\hline T6 & 0.81 & 0.85 & 1.34 & 1.44 & 1.53 & 1.60 & 1.65 \\
\hline T7 & 0.93 & 0.95 & 1.36 & 1.49 & 1.61 & 1.68 & 1.75 \\
\hline T8 & 0.96 & 0.98 & 1.46 & 1.54 & 1.69 & 1.72 & 1.77 \\
\hline T9 & 0.82 & 0.83 & 1.20 & 1.39 & 1.48 & 1.49 & 1.55 \\
\hline T10 & 0.84 & 0.86 & 1.39 & 1.51 & 1.59 & 1.62 & 1.69 \\
\hline T11 & 0.96 & 0.98 & 1.38 & 1.59 & 1.71 & 1.72 & 1.74 \\
\hline T12 & 0.99 & 1.00 & 1.49 & 1.68 & 1.73 & 1.74 & 1.76 \\
\hline C.D. at 5\% & 0.01 & 0.01 & 0.71 & 0.03 & 0.01 & 0.01 & 0.01 \\
\hline
\end{tabular}

Table.10 Amount of carbon dioxide evolution ( $\mathrm{mg} \mathrm{CO}_{2} / 100 \mathrm{~g}$ compost) in mature compost

\begin{tabular}{|l|l|l|l|l|c|}
\hline \multirow{2}{*}{ Treatment } & \multicolumn{5}{|c|}{ Incubation time (weeks) } \\
\cline { 2 - 6 } & \multicolumn{1}{|c|}{$\mathbf{1}$} & \multicolumn{1}{|c|}{$\mathbf{4}$} & $\mathbf{3}$ & Total \\
\hline T1 & 148.40 & 136.02 & 122.20 & 98.5 & 505.1 \\
\hline T2 & 41.10 & 38.20 & 32.50 & 30.60 & 142.4 \\
\hline T3 & 110.30 & 106.40 & 96.80 & 68.50 & 382.0 \\
\hline T4 & 108.20 & 102.70 & 92.40 & 65.20 & 368.5 \\
\hline T5 & 96.40 & 80.60 & 70.90 & 50.50 & 298.4 \\
\hline T6 & 94.50 & 75.20 & 55.30 & 35.20 & 260.2 \\
\hline T7 & 118.80 & 97.40 & 85.40 & 70.10 & 371.7 \\
\hline T8 & 109.30 & 90.30 & 82.30 & 60.40 & 342.3 \\
\hline T9 & 105.90 & 85.60 & 68.20 & 46.90 & 306.6 \\
\hline T10 & 102.80 & 70.10 & 60.40 & 40.20 & 273.5 \\
\hline T11 & 120.60 & 100.10 & 85.40 & 50.30 & 356.4 \\
\hline T12 & 145.20 & 120.50 & 95.10 & 60.20 & 421.0 \\
\hline C.D. at 5\% & 1.9 & 3.1 & 2.9 & 2.8 & 4.2 \\
\hline
\end{tabular}

\section{Total K}

Total potassium content increased significantly with the progress of decomposition in all the treatments. Total Kincreased from 0.89 and $0.72 \%$ to 1.53 and
$1.02 \%$ in controls, which were having paddy straw alone and pressmud alone with cattle dung $(10 \%)$. Total potassium was highest at the end of 90 days of composting. Among all the treatments, maximum total potassium content was observed in T8 $(1.77 \%)$ having 
paddy straw and press mud (2:1) +cattle dung $(10 \%)+$ microbial consortia.

\section{Carbon dioxide evolution}

Table 9 shows the amount of carbon dioxide evolution in the composts over a period of 4 weeks. Maximum amount of carbon dioxide evolution was seen in treatment T1 $(505.1 \mathrm{mg}$ $\mathrm{CO}_{2} / 100 \mathrm{~g}$ compost) having paddy straw alone + cattle dung (10\%) followed by treatment T12 (421.0 mg $\mathrm{CO}_{2} / 100 \mathrm{~g}$ compost) having paddy straw and pressmud (3:1) + cattle dung $(10 \%)$. The minimum carbon dioxide evolution was observed in the treatment $\mathrm{T}$ 2(142.4 $\mathrm{mg} \quad \mathrm{CO}_{2} / 100 \mathrm{~g}$ compost) having pressmud alone + cattle dung $(10 \%)$ followed by treatment T6 (260.2 mg $\mathrm{CO}_{2} / 100 \mathrm{~g}$ compost) having paddy straw and pressmud $(1: 2)+$ cattle dung $(10 \%)+$ microbial consortia (Table 10).

In conclusion the co-composting of paddy straw and pressmud in different ratio with or without microbial consortia was carried out in pits. Two turnings were given after 15 and 30 days of intervals. Samples were drawn at 0, $15,30,45,60,75$ and 90 days for analysis of different parameters such as $\mathrm{C}, \mathrm{N}, \mathrm{P}, \mathrm{K}$ contents.

Total organic carbon was 47.96 and $36.27 \%$ initially in control and decreased to 35.10 and $25.15 \%$ respectively after 90 days of composting. Minimum organic C $(19.39 \%)$ was recorded in the treatment $\mathrm{T} 6$ having paddy straw and pressmud $(1: 2)+$ Cattle dung $(10 \%)+$ microbial consortia after 90 days of composting as compared to controls (T1 and T2) and other treatments.

Total $\mathrm{N}$ content increased significantly from $0.80 \%$ and 1.07 to 1.04 and $1.12 \%$ during composting in control (T1 and T2). Maximum total N (1.25\%) was present in treatment $\mathrm{T} 6$ having paddy straw and pressmud (1:2) + Cattle dung $(10 \%)+$ microbial consortia after 90 days of composting followed by treatment $\mathrm{T} 5(1.23 \%)$ having paddy straw and pressmud (1:2) + Cattle dung $(10 \%)$.

Amount of nitrate-nitrogen increased significantly and varied from 180 $\mathrm{mg} / \mathrm{kg}$ to $527 \mathrm{mg} / \mathrm{kg}$ and was maximum in the treatment T6 (527 $\mathrm{mg} / \mathrm{kg}$ ) having paddy straw and pressmud $(1: 2)$ +cattle dung $(10 \%)+$ microbial consortia and minimum for treatment T1 (394 $\mathrm{mg} / \mathrm{kg})$ having paddy straw alone + cattle dung $(10 \%)$ after 90 days of composting.

A significant reduction in $\mathrm{C}$ : $\mathrm{N}$ ratio in the compost was observed in all the treatments. The $\mathrm{C}: \mathrm{N}$ ratio declined from 59.95 and 33.89 to 33.75 and 22.45 in controls (T1 and T2) respectively, after 90 days of composting. With the addition of microbial consortia, decline in $\mathrm{C} / \mathrm{N}$ ratio was more as compared to other treatments which were not having microbial consortia. Treatment T6 having paddy straw and pressmud (1:2) + cattle dung $(10 \%)+$ microbial consortia had minimum $\mathrm{C} / \mathrm{N}$ ratio (15.51).

Total P content increased significantly in composting of paddy straw and pressmud in different ratios with or without microbial consortia. Amount of total $\mathrm{P}$ varied from 185 to 1035 $\mathrm{mg} / \mathrm{kg}$. Initially it was 250 and 185 $\mathrm{mg} / \mathrm{kg}$ in control and increased to 659 and $332 \mathrm{mg} / \mathrm{kg}$ respectively after 90 days of composting. Maximum amount of total $\mathrm{P}$ was observed in treatments T6 (1035 mg/kg) after 90 days of composting followed by T10 (1020 $\mathrm{mg} / \mathrm{kg}$ ).

Total potassium content increased significantly with the progress of 
decomposition in all the treatments. Total potassium increased from 0.89 and $0.72 \%$ to 1.53 and $1.02 \%$ in controls, which were having paddy straw alone and pressmud alone with cattle dung (10\%). Total potassium was highest at the end of 90 days of composting. Among all the treatments, maximum total potassium content was observed in T $8(1.77 \%)$ having paddy straw and press mud $(2: 1)$ +cattle dung $(10 \%)+$ microbial consortia.

\section{References}

Joshi, N. and Sharma, S. (2010) Physico chemical characterization of sulphidation pressmud composted and vermicomposted pressmud, Report and Opinion, 2(3), 79-82.

Patil, N.N., Jadhar, S., Goborpade, S.S. and Sharma, A.K.B. (2000) Isolation and enrichment of sugar pressmud adapted microorganisms for production of biofertilizer by using sugar pressmud. International Journal of Advance Biotechnology Research, 4(1), 96-104.

Ramaswamy, P.P. (1999) Recycling of agricultural and agro-industry waste for sustainable agricultural production. Journal of International Society of Soil Science, 47(4), 661-665.

Reinhard, T.E., Ottmar, R.D. and Castillo, C. (2001) Smoke impacts from agricultural burning in a rural Brazilian town. Journal of Air and Waste Management Association, 51, 443-450.

Sidhu, B.S., Beri, V., Singh, J. and Pannu, R.P.S. (2003) Crop residues and their utilization for crop production In: Recycling of rural and urban wastes a review. Department of Soils, PAU, Ludhiana, Pp. 1-35.

Solomon, S. (2011). Sugarcane based industries in India. Sugar Technology, 13(4), 408-416.

Tipayarom, D. and N, Oanh. (2007) Effects from open rice straw burning emission on air quality in the Bangkok Metropolitan Region. Science Asia. 33, 339-345.

Torigoe, K., Hasegawa, S., Numata, O., Yazaki, S., Matsunaga, M., Boku, N., Hiura, M. and Ino, H. (2000) Influence of emission from rice straw burning on bronchial asthma in children, Pediatrics International, 21, 56-59.

Van der Poel, P.W., Schiweck, H. and Schwartz, T. (1998) Beet and cane sugar manufacture. Sugar Technology, $11,1005$.

Zeyer, J., Rangana, L.S. and Chandra, T.S. (2004) Pressmud as biofertilizer for improving soil fertility and pulse crop productivity. ISCB- Swis Collaboration in Biotech. A Report Portfolio. First phase (1999-2004).

\section{How to cite this article:}

Sushila Devi, Nandni, Tanvi and Sneh Goyal. 2021. Qualitative Assessment of Co-compost Prepared by Paddy straw and Pressmud using Microbial Consortia. Int.J.Curr.Microbiol.App.Sci. 10(01): 220-230. doi: https://doi.org/10.20546/ijcmas.2021.1001.027 